\title{
СОВРЕМЕННЫЕ ИЗМЕНЕНИЯ ВОДНОГО РЕЖИМА И МОРФОМЕТРИИ РЕК ВЕРХНЕДОНСКОГО БАССЕЙНА
}

\author{
(C) 2020 г. В. А. Дмитриева* \\ Воронежский государственный университет, Воронеж, Россия \\ *e-mail:verba47@list.ru \\ Поступила в редакцию 10.01.2019 г. \\ После доработки 22.02.2019 г. \\ Принята к публикации 03.10.2019 г.
}

\begin{abstract}
В статье приводится обоснование выделения частей бассейна р. Дон - Верхней и Средней. Предлагается границу, до настоящего времени не имеющей четкого проведения, совместить с административной границей Воронежской области на юге и юго-востоке, востоке и северо-востоке. Предложенный подход позволил рассматривать водный режим собственно Дона и притока Хопра одновременно как частей единого бассейна Верхнего Дона. Годовой речной сток Дона и Хопра снижается, но тенденция слаба и статистически незначима. Весеннее снеговое половодье удлиняется по продолжительности, как за счет более раннего наступления, так и более позднего окончания. Максимальные расходы воды стабильно снижаются, что является следствием изменения генезиса максимальных расходов воды в условиях глобального потепления и снижения промерзания почвы. Участились случаи установления максимума половодья в марте, не отмечавшиеся до начала 1970-х годов, а также повышения повторяемости в мае при снижении традиционного преобладания в апреле. Абсолютные минимумы летне-осенней межени смещаются все в большем числе случаев на сентябрь, а зимней межени - на февраль и март, к началу половодья. Происходит сокращение неравномерности сезонного распределения речного стока и более длительное сохранение в течение года близкой к средней водности. Предвесенние февральские оттепели и паводки, изменение характера весеннего половодья и генезиса максимумов, неглубокое промерзание почвы, уменьшение продолжительности контакта талой воды с почвой и разрушение ручейковой сети и склонового стока ведут к трансформации морфометрии рек. Наблюдается ускоренный процесс сокращения длины малых водотоков, увеличение числа суходолов, высохших русел, эпизодических водотоков. На примере pр. Сосна и Каменка, правобережных притоков Дона, выявлено снижение протяженности речной сети на 8.2 и $45 \%$ соответственно, наиболее интенсивное в текущем столетии.
\end{abstract}

Ключевые слова: Верхний Дон, гидрологический режим, длина рек, динамика водности, деградация водотоков

DOI: $10.31857 / \mathrm{S} 2587556620010070$

\section{ВВЕДЕНИЕ}

Река Дон, ее речная система и бассейн являются объектами пристального научного внимания, поскольку велика практическая значимость ее стока для 15 субъектов Российской Федерации, располагающихся на ее водосборе. В текущем столетии появились публикации, в которых анализируются водные ресурсы Дона [3], приводятся сценарии перспективных изменений водности [4, 26], уточняются количественные показатели водных ресурсов, рассматриваются экологические вопросы $[7,9]$, предлагается схема комплексного использования и охраны водных объектов Дона [25].

В статьях [10, 12, 15, 29 и др.], посвященных исследованию гидрологического режима Дона, анализируются пространственно-временна́я изменчивость основных гидрологических характеристик среднегодового, максимального и минимального речного стока, генезис и особенности снегового половодья и межени, сезонное распределение стока в современных климатических и хозяйственных условиях. К наименее освещенным аспектам исследований относится современная морфометрия рек и ее связь с водностью реки. В то же время изменения водного режима и морфометрии - взаимосвязанные и взаимообусловленные процессы. В данном исследовании на примере анализируется динамика водности и протяженности рек Верхнего Дона и их связь.

\section{Граница Верхнего и Среднего Дона в методике исследования}

В современных научных публикациях отсутствует четкое представление о водоразделе бас- 
сейна Верхнего Дона. Как известно, большие реки от истока к устью условно делятся на три части: верхнее, среднее и нижнее течение, различающиеся между собой по ряду гидрологических, морфологических и морфометрических признаков. Строгой рекомендации подобного разделения не существует, очевидно, по этой причине о выделении Верхнего Дона из общей протяженности реки и ее бассейна высказано множество мнений.

Так, П.П. Семенов [24, с. 119-124] о р. Дон сказал, что "Все течение разделено на 3 части: верхнее от истока до устья р. Воронеж; среднее от устья р. Воронеж до Качалинской станции, т.е. до места наибольшего сближения Дона с Волгой, и нижнее от Качалинской станции до устья". Л.К. Давыдов [5] поддержал данную точку зрения, приведя в качестве аргумента средний уклон реки для трех участков: от истока Дона до устья впадающего притока Воронеж $(i=0.00025)$; далее от устья р. Воронеж до г. Калач $(i=0.00006)$; в нижней части от г. Калач до устья р. Дон $(i=0.00002)$.

В ряде публикаций: гидрогеологов [25]; геоморфологов [14 и др.]; ландшафтоведов [18, 20, 30 и др.]; ботаников [1]; экологов [6, 21] - граница между Верхним и Средним Доном по умолчанию подразумевается проходящая через устье р. Воронеж.

В некоторых исследованиях Верхний Дон от Среднего Дона отделяют гидростворами г. Задонск [7] и г. Лиски [2, 7], а также устьем р. Тихая Сосна, что северо-западнее г. Лиски [23]. Ниже названных мест указал границу Верхнего Дона А.Г. Курдов [17], совмещая ее с гидроствором ст. Казанская на Дону. В других публикациях [16] автор соглашался с ограничением Верхнего Дона устьем р. Воронеж.

При отсутствии четких критериев и аргументов для деления рек на части, очевидно, необходимо исходить из природных условий формирования стока, задач исследования, водохозяйственной целесообразности и водохозяйственных расчетов. Совмещение границы Верходонья с местоположением гидростворов Задонск, Лиски, Казанская на p. Дон вряд ли правомерно. Так, при устройстве стационарных пунктов гидрологической сети закладываются специфические принципы, направленные на получение наиболее достоверной первичной информации об элементах жидкого и твердого стока, температуре воды, компонентах химического состава на главной реке и ее притоках. Важной составляющей организации сети является размещение створов ниже впадения крупных притоков с целью учета боковой приточности и изменения водности по длине реки. Очевидно, что данные требования не могут служить основанием для выделения бассейновой части Верхнего Дона.
В контексте данного исследования за разделительную границу Верхнего и Среднего Дона принята линия, пересекающая рр. Дон и Хопер и совпадающая с границей Воронежской области на юге и юго-востоке, востоке и северо-востоке. При этом делении, прежде всего, сохраняется единство физико-географических условий формирования речного стока, так как большая часть бассейна располагается в лесостепной природной зоне, а небольшая доля размещения в северной степной зоне лишь подчеркивает роль природных факторов в образовании гидрологических процессов. Помимо этого, для расчета территориальных водных ресурсов, водообеспеченности, морфометрических показателей речных систем Воронежской и Липецкой областей, по территории которых ранее предлагалось разграничивать Верхний и Средний Дон, более целесообразно совместить рубежи Верхнего Дона и Воронежской области. Таким образом, граница Воронежской области отделяет Верхний Дон от Среднего Дона. На востоке и северо-востоке граница пересекает p. Хопер и разделяет Воронежскую и Волгоградскую области. При данном ограничении Верхнего Дона в рассмотрение попадает часть бассейна р. Хопер, образующей в верховье обособленную от Дона территорию, но крайне важную для параллельного анализа пространственно-временно́й изменчивости гидрологического режима рек, оценки водных ресурсов, морфометрии и иных гидрологических параметров водных объектов Воронежской области.

Исходя из данных рассуждений, площадь Верхнего Дона, включая бассейн Хопра, очерченная по административной границе Воронежской области, равна $143500 \mathrm{KM}^{2}$, что составляет примерно одну треть от общей площади речного бассейна Дона. Длина Дона до пересечения границы Воронежской и Ростовской области насчитывает около 900 км. Площадь бассейна Хопра до линии разграничения Воронежской и Волгоградской областей, куда устремляется Хопер, равна 35200 км² $^{2}$ а длина - около 1560 км [8].

\section{ГИДРОЛОГИЧЕСКАЯ ИЗУЧЕННОСТЬ ВЕРХНЕГО ДОНА}

Гидрологическая сеть станций и постов до середины 1980-х годов была достаточно густой и размещалась на больших, средних и малых реках. При этом гидропостов на Дону было 2, Хопре -4 , их притоках -65 , включая посты на временных водотоках Нижнедевицкой воднобалансовой станции и Каменностепной гидрометеорологической обсерватории. Среди них опорные посты: ДонЛиски, Хопер-Поворино с рядами наблюдений свыше 100 лет. К пунктам с продолжительными рядами наблюдений, пригодными для статистической обработки и анализа, относятся Красивая Меча- 
Ефремов, Сосна-Елец, Воронеж-Липецк, БитюгБобров, Подгорная-Калач, Хопер-Пановка, ХоперБалашов, Хопер-Новохоперск, Ворона-Борисоглебск, Савала-Жердевка. Но в настоящее время гидрологическая сеть продолжает сокращаться. Оптимизация гидрологической сети страны привела к закрытию постов на малых реках: руч. Репный-Краснореченка, Осередь-Бутурлиновка, Россошь-Подгоренский, Ведуга-Акулово, Черная Калитва-Ольховатка, Елань-Елань-Коленовский и многих других, и практическому свертыванию уникальных гидрологических наблюдений Нижнедевицкой воднобалансовой станции и Каменностепной обсерватории в Воронежской области. К примеру, р. Черная Калитва, по Ф.Н. Милькову [28], является пограничной между лесостепью и степью и ее водный режим интересен с позиции формирования стока, а р. Елань в связи с разведкой и планируемой дальнейшей разработкой никелевых руд в ее бассейне, на территории Новохоперского района Воронежской области, - в прикладном аспекте. Для изучения динамики морфометрии рек наблюдения на малых водотоках весьма иллюстративны, поскольку именно малые водотоки наиболее чувствительны ко всем внешним воздействиям природного и антропогенного характера. По состоянию на 01.01.2018 г. в бассейне Верхнего Дона насчитывается 23 постоянно действующих гидропостов. Материалы наблюдений на них используются и для настоящего исследования.

\section{ВОДНЫЙ РЕЖИМ}

Река Дон с притоками Красивая Меча, Сосна (Быстрая Сосна), Воронеж, Битюг, Тихая Сосна, Черная Калитва и др. и р. Хопер с притоками Ворона, Савала и др. формируют речные системы и водные ресурсы Верхнего Дона. Наиболее динамично изменяющимся в гидрологическом режиме рек является водный сток. Однако средний годовой сток, сток половодья и межени по характеру и направленности изменений существенно отличаются.

Среднегодовой сток является важнейшей характеристикой в оценке водных ресурсов, территориальной и удельной водообеспеченности и хозяйственного использования поверхностных вод в отраслях экономики. Анализ среднегодового стока за многолетний период от начала наблюдений на постах в бассейне Дона по 2017 г. включительно показал отсутствие выраженных тенденций. Колебания стока происходят около средней многолетней величины с трендом роста в р. Красивая Меча-г. Ефремов и прямо противоположным трендом в р. Сосна-г. Елец (рис. 1).

Речные бассейны рр. Красивая Меча и Сосна расположены на правобережье Дона, их устья отстоят всего на расстоянии 37 км друг от друга. В p. Дон, по данным нижерасположенных постов г. Задонск и г. Лиски, также наблюдается некотоpoe, статистически незначимое снижение годового стока, аналогичное таковому р. Сосна (рис. 2).

Подобные изменения стока отмечаются в p. Хопер в створах Поворино и Новохоперск. Рост годового стока отмечен в р. Ворона - г. Борисоглебск, впадающей в Хопер между указанными гидростворами. Для осмысления подобных аномалий требуются дополнительные наблюдения за стоком.

В значениях годового стока большинства рек Верхнего Дона прослеживается снижение, но тенденция слаба и статистически незначима. Исходя из этого, можно заключить, что водные ресурсы Верхнего Дона, рассчитываемые по величине годового речного стока, относительно стабильные.

Современные климатические изменения больше влияют на сток половодья и межени. Объемы весеннего половодья снижаются, а объемы стока межени, особенно зимней, растут $[3,7,9,10]$. Одновременно происходят соответствующие изменения в сроках наступления экстремумов половодного и меженного стока. На примере р. Ворона-г. Борисоглебск в текущем столетии частота образования максимумов водности снижается в апреле, но увеличивается в марте и мае. До начала 1970-х гг. случаев образования наивысших расходов воды в марте не отмечалось (рис. 3).

Несмотря на снижение стока весеннего половодья, истощение водных запасов в период межени в XXI в. происходит медленнее, чем в период 1944-2000 гг. Абсолютные минимумы летнеосенней межени смещаются все в большем числе случаев на сентябрь, а зимней межени - на февраль и март, к началу половодья (рис. 4). Следовательно, происходит снижение неравномерности сезонного распределения речного стока и более длительное сохранение снеднегодовой величины водности.

Запасы воды в снежном покрове накануне снеготаяния, метеорологические условия и потери талых вод во время половодья определяют формирование максимального стока и максимальных расходов воды. Велика роль почвы, как “посредника”, по выражению М.И. Львовича, между метеорологическими и гидрологическими явлениями. Ее осеннее увлажнение и зимнее промерзание во многом определяют ход и объем весеннего половодья. Достаточно заметить, что глубина промерзания почвы в последние десятилетия заметно снизилась. Так, в зиму 2016/2017 г. оно составило в Воронежской области рекордно низкую величину $-17-33$ см. При столь небольшой глубине промерзания почвы даже незначительное прогревание воздуха ведет к оттаиванию верхнего слоя почвы, способной принимать первые объемы талой воды. Именно таким был про- 


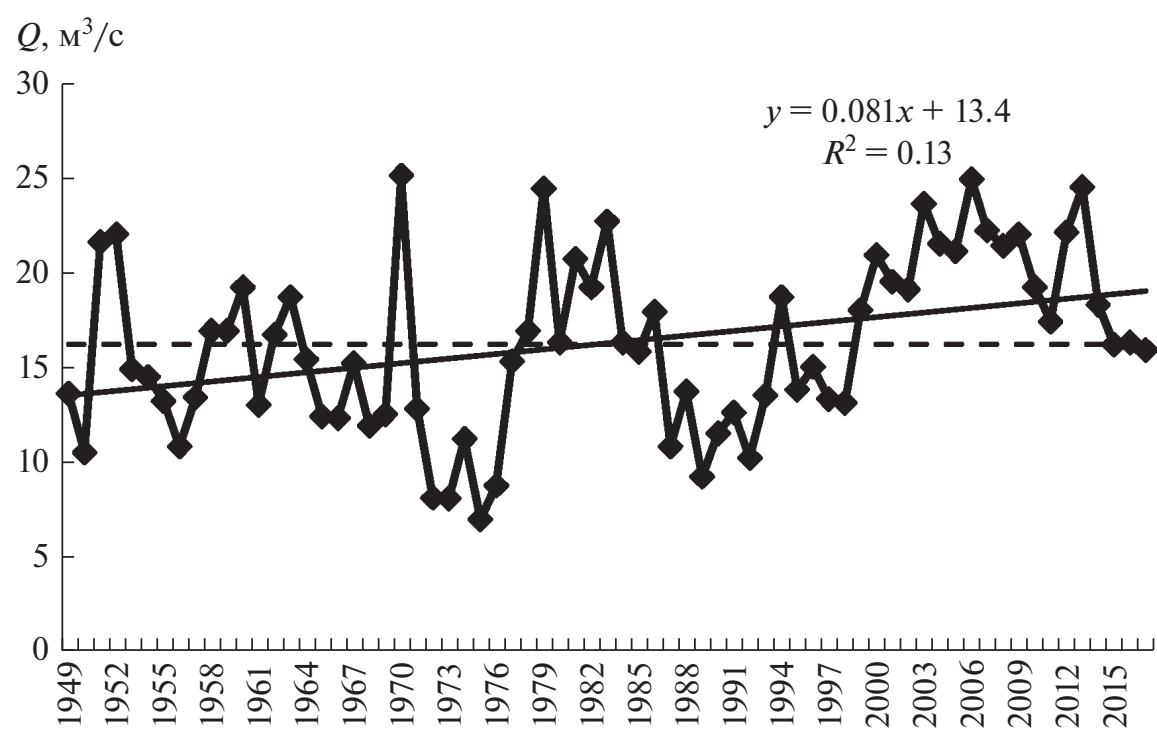

$Q, \mathrm{~m}^{3} / \mathrm{c}$

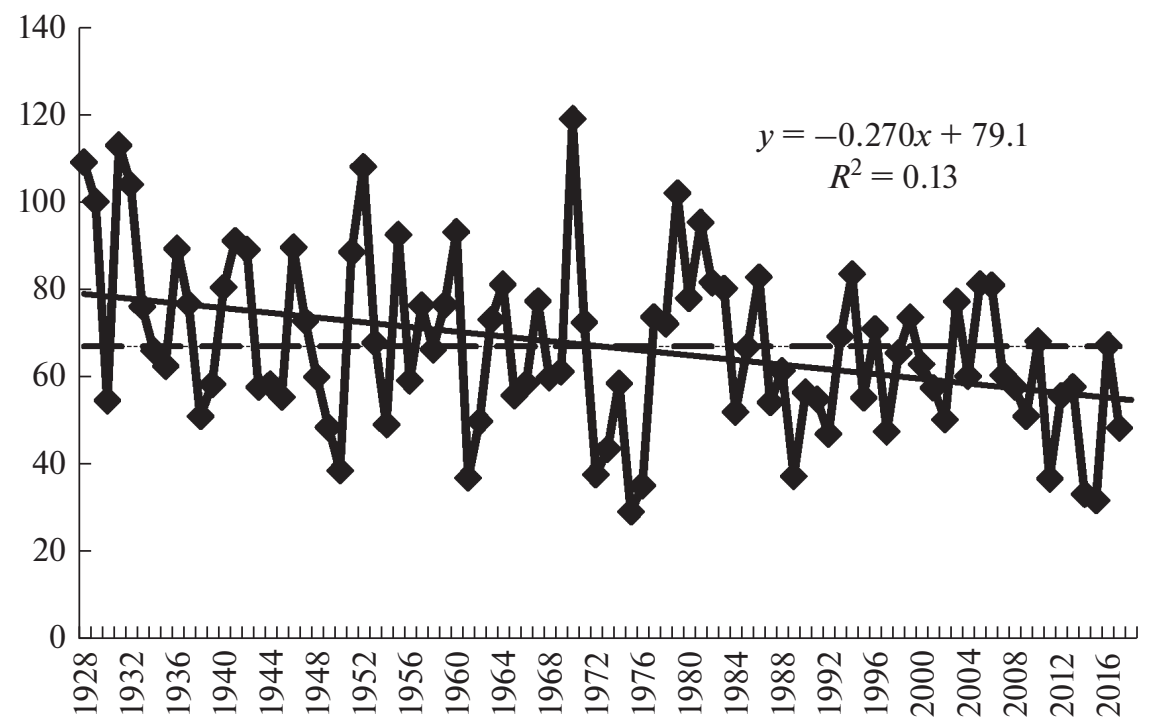

Рис. 1. Среднегодовой сток рек за период мониторинга.

цесс снеготаяния весной 2017 г. в воронежской части Донского бассейна. За зиму 2016/2017 г. сформировались достаточные для среднестатистического половодья снегозапасы, но в результате неспешного нарастания температуры воздуха весной и высокой поглощающей способности почвы после ее оттаивания талые снеговые воды интенсивно инфильтруются в почву. Из-за высокой потери талой воды на увлажнение почвогрунтов и пополнение запасов грунтовых вод поверхностный максимальный сток был ниже многолетних значений и самым низким в р. Соснаг. Елец за период мониторинга (рис. 5).

\section{ДИНАМИКА МОРФОМЕТРИИ РЕК}

Современное формирование максимального стока, его генезис не способствуют образованию склонового стока и ручейковой сети. При малом объеме стока половодья талая снеговая вода заполняет русловую емкость и часто не выходит из берегов, например, в 2010, 2014, 2017 гг. в бассейне Верхнего Дона. Незначительные объемы воды на склонах затрачиваются на инфильтрацию и испарение, не достигая русла реки. Уменьшение объемов половодья, сокращение контакта талых вод с поверхностью склонов речной долины, исчезновение струек воды и ручейковой сети в момент снеготаяния становятся главной природной причиной динамики морфометрии рек. Маловодье в бассейне Дона, отмечаемое в 2007-2015 гг. [7], ведет к деградации водотоков, особенно малых и самых малых. Она заключается в усыхании рек в верховьях до суходолов, полном пересыхании и исчезновении самых малых водотоков. Не- 


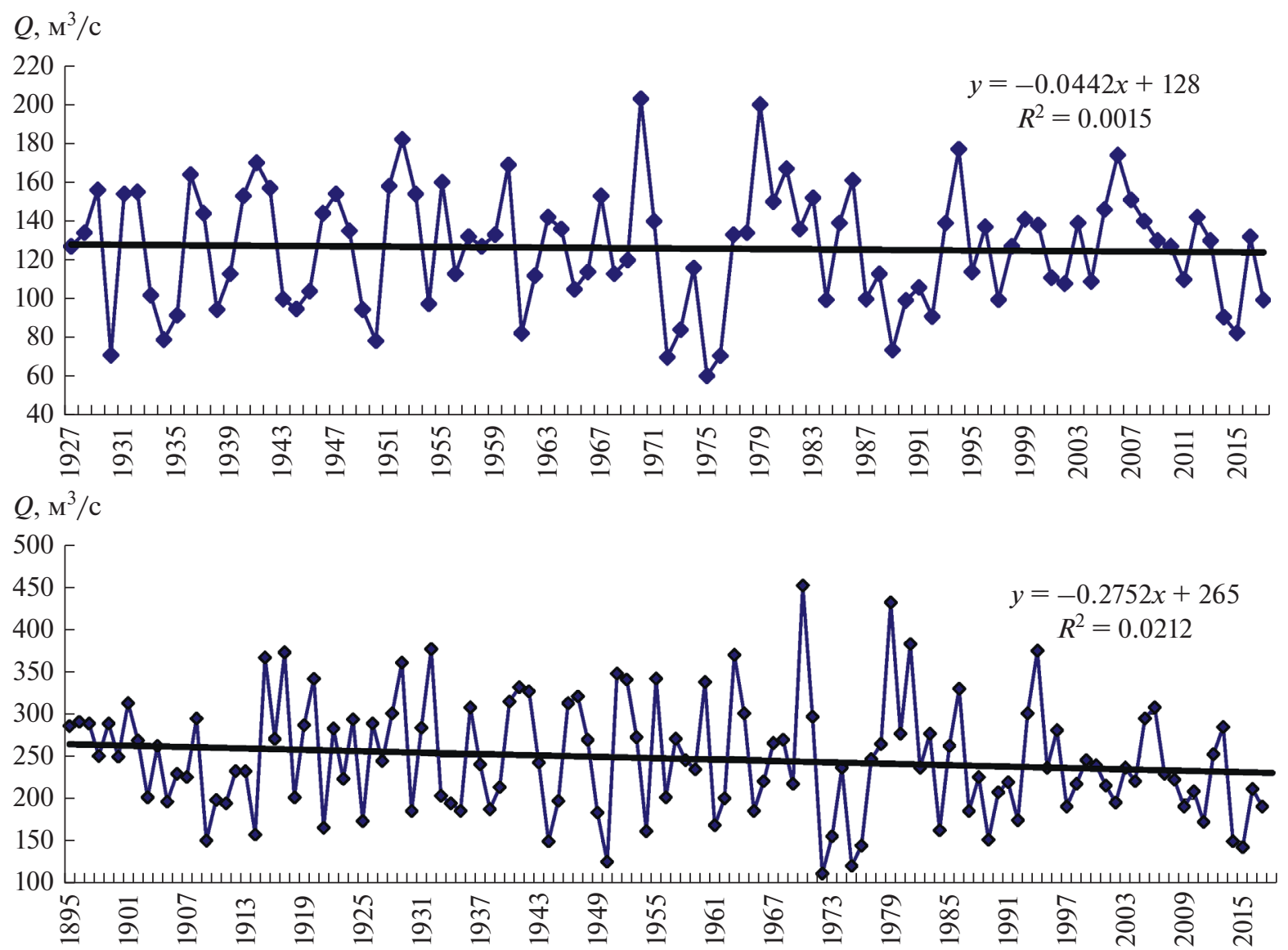

Рис. 2. Среднегодовой сток р. Дон за период мониторинга.

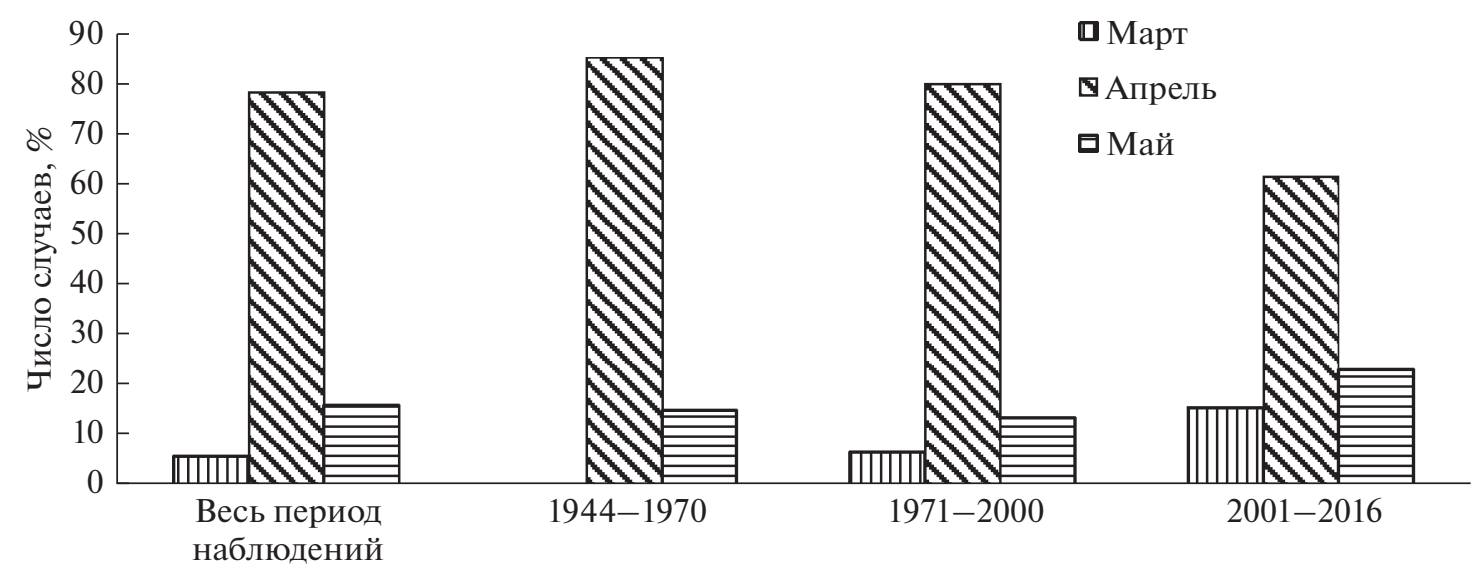

Годы

Рис. 3. Наступление экстремумов высокой водности в р. Ворона-г. Борисоглебск за 1944-2016 гг.

редко реки превращаются в отдельные плесы, заполненные водой и не связанные между собой в межень, как, например, р. Икорец - левобережный приток Дона. Процессы деградации водотоков ве- дут к сокращению их числа, уменьшению протяженности речной сети и густоты речной сети.

Полевые обследования рр. Сосна и Каменка, правобережных притоков Дона на территории 

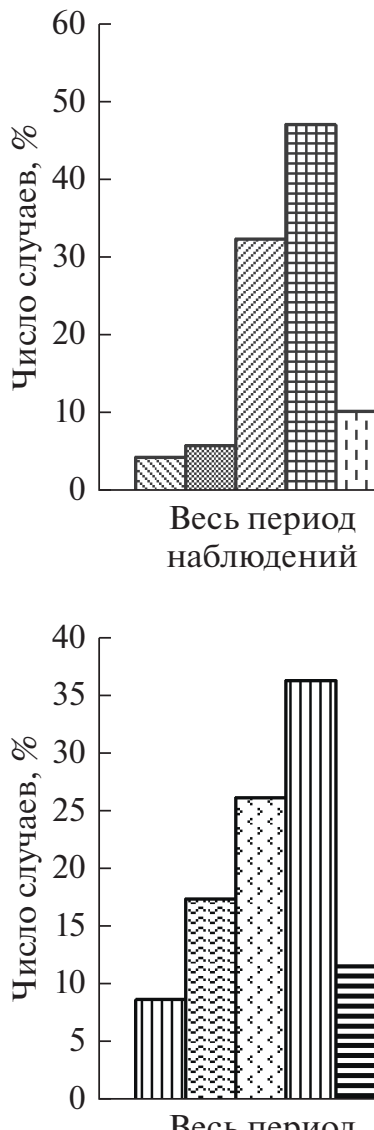
наблюдений (a)

目юнь

图 Июль

口 Август

由 Сентябрь

口 Октябрь

Годы

(б) глебск.

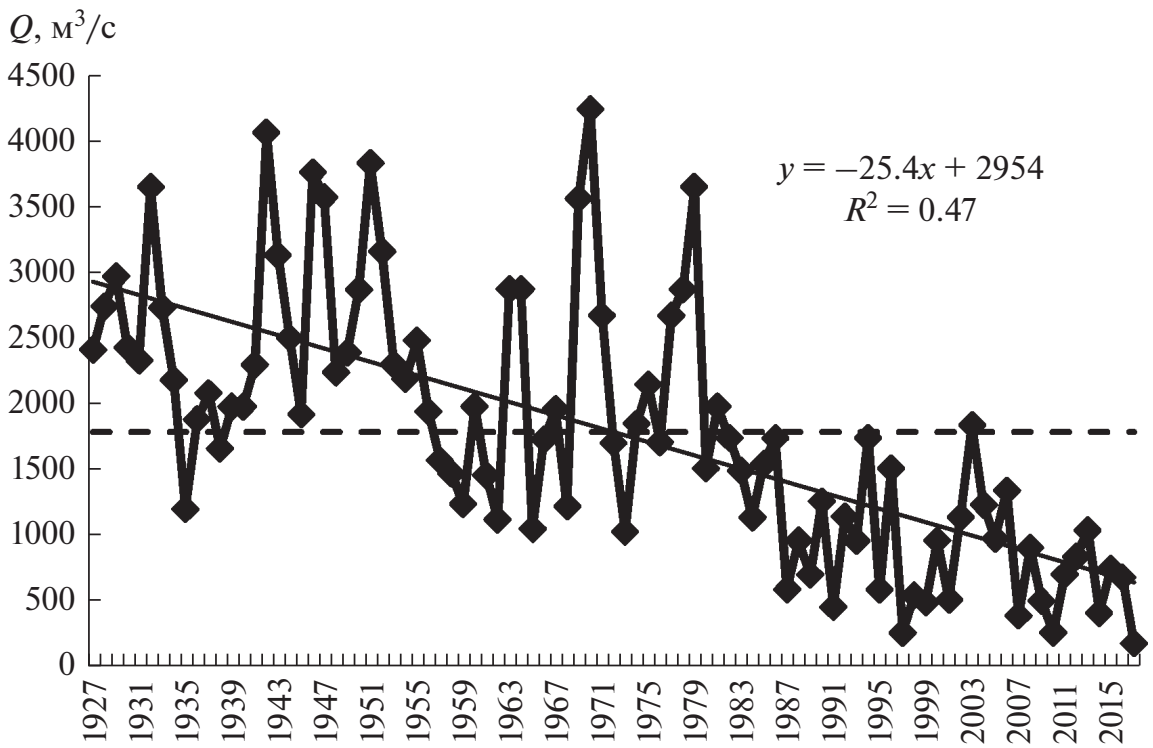

Рис. 5. Максимальные расходы воды весеннего половодья р. Сосна-г. Елец. 
Таблица 1. Динамика морфометрии р. Сосна и ее притоков

\begin{tabular}{|c|c|c|c|c|}
\hline \multirow{2}{*}{ Название водотока } & \multirow{2}{*}{$\begin{array}{c}\text { Куда впадает } \\
\text { и с какого берега (лв, пр) }\end{array}$} & \multicolumn{2}{|c|}{ Длина, км } & \multirow{2}{*}{$\begin{array}{c}\text { Изменение длины, } \\
\text { км/\% }\end{array}$} \\
\hline & & по [22] & по [11] & \\
\hline Сосна & Дон, пр & 296 & 294 & $-2 / 1$ \\
\hline Корытино & Сосна, лв & 31 & 0 & $-31 / 100$ \\
\hline Тальчик & Сосна, лв & 13 & 7 & $-6 / 46$ \\
\hline Пальна & Сосна, лв & 51 & 47 & $-4 / 8$ \\
\hline Ельчик & Сосна, лв & 25 & 18 & $-7 / 28$ \\
\hline Пажень & Сосна, лв & 24 & 14 & $-10 / 42$ \\
\hline Воронец & Сосна, пр & 20 & 12 & $-8 / 40$ \\
\hline Воргол & Сосна, лв & 64 & 63 & $-1 / 2$ \\
\hline Паниковец & Сосна, пр & 21 & 18 & $-3 / 14$ \\
\hline Свишня & Сосна, пр & 36 & 36 & 0 \\
\hline Ясенок & Сосна, лв & 25 & 25 & 0 \\
\hline Большая Чернава & Сосна, лв & 54 & 53 & $-1 / 2$ \\
\hline Олым & Сосна, пр & 151 & 151 & 0 \\
\hline Хмелевой & Сосна, лв & 12 & 12 & 0 \\
\hline Паниковец (Орлов. обл.) & Сосна, пр & 23 & 10 & $-13 / 57$ \\
\hline Кунач & Сосна, лв & 29 & 29 & 0 \\
\hline Кшень & Сосна, пр & 135 & 124 & $-11 / 8$ \\
\hline Ливенка & Сосна, лв & 32 & 30 & $-2 / 6$ \\
\hline Труды & Сосна, лв & 89 & 87 & $-2 / 2$ \\
\hline Речица & Сосна, лв & 13 & 13 & 0 \\
\hline Тим & Сосна, пр & 120 & 120 & 0 \\
\hline Фошня & Сосна, лв & 52 & 52 & 0 \\
\hline Дайменка & Сосна, пр & 24 & 23 & $-1 / 4$ \\
\hline Сучья & Сосна, пр & 24 & 15 & $-9 / 38$ \\
\hline Синьковец & Сосна, пр & 21 & 18 & $-3 / 14$ \\
\hline \multicolumn{2}{|l|}{ Суммарная протяженность, } & 1385 & 1271 & $-114 / 8.2$ \\
\hline
\end{tabular}

Орловской и Липецкой областей [13, 19], указывают на стремительную деградацию рек, уменьшение их протяженности, особенно в текущем столетии. Базовыми источниками для сравнения приняты сведения из "Ресурсов поверхностных вод” [22]. Современное состояние оценивалось по космоснимкам дистанционного зондирования Земли и маршрутным обследованиям рек. В морфометрии р. Сосна на территории Орловской и особенно Липецкой областей отмечены существенные изменения (табл. 1).

Суммарная протяженность рек в речной системе Сосны сократилась на 114 км, или на $8.2 \%$. Полностью исчез водоток Корытино, сохранилось лишь его гидрографическое русло, “скелет" некогда руслового потока. На грани исчезновения - pр. Пажень, Паниковец, Сучья. Значительно сокращается р. Кшень - один из трех, наряду с pp. Тим и Олым, значительных притоков Сосны. Отмечена даже трансформация водотоков, которые круглогодично питаются родниковой водой. Среди них - Ельчик, Плющань и др.

В большей степени истощаются очень малые реки, протяженностью до 10 км. Они, как правило, имеют только поверхностное питание за счет стока половодья и дождевых паводков. Но дождевые паводки - большая редкость, и снеговое половодье - исключительный источник питания. Таким редким событием стал дождевой паводок на спаде весеннего половодья 2016 г., образовавшийся от обильных и растянувшихся с апреля по май жидких осадков. Благодаря длительным и интенсивным осадкам оживились ручейки на склонах водосборов, заполнились русловые емкости малых речушек. В последующие годы повторения паводка не наблюдалось, поэтому продолжается устойчивое изменение морфометрии рек.

В качестве объекта исследования динамики морфометрии малых рек взята р. Каменка, право- 
Таблица 2. Динамика морфометрии р. Каменка и ее притоков

\begin{tabular}{|c|c|c|c|c|c|}
\hline \multirow{2}{*}{$\begin{array}{l}\text { № } \\
\Pi / \Pi\end{array}$} & \multirow{2}{*}{ Название водотока } & \multirow{2}{*}{$\begin{array}{c}\text { Куда впадает и с какого } \\
\text { берега (лв, пр) }\end{array}$} & \multicolumn{2}{|c|}{ Длина, км } & \multirow{2}{*}{$\begin{array}{c}\text { Изменение длины, } \\
\text { км/\% }\end{array}$} \\
\hline & & & по [11] & по [19] & \\
\hline 1 & Каменка & Дон, пр & 33.4 & 20.9 & $-12.5 / 60$ \\
\hline 2 & б/н в 0.5 км к 3 от н.п. Ивлевка & Каменка, пр & 1.1 & прсх & $-1.1 / 100$ \\
\hline 3 & б/н в 0.5 км к Ю от н.п. Ивлевка & $»$, лв & 0.5 & прсх & $-0.5 / 100$ \\
\hline 4 & б/н в 1.2 км к В от н.п. Комбаровка & », лв & 1.4 & прсх & $-1.4 / 100$ \\
\hline 5 & б/н в 0.8 км к ЮВ от н.п. Секретаровка & », пр & 0.5 & прсх & $-0.5 / 100$ \\
\hline 6 & б/н в 1.6 км к С3 от н.п. Владимировка & », пр & 3.3 & 1.5 & $-1.8 / 55$ \\
\hline 7 & б/н в 1.1 км к 3 от н.п. Владимировка & », лв & 0.7 & прсх & $-0.7 / 100$ \\
\hline 8 & б/н в 1.9 км к ЮЗ от н.П. Крутой Верх & », пр & 2.7 & 0.8 & $-1.9 / 70$ \\
\hline 9 & б/н в 2.7км к СВ от н.п. Каменский & $»$, пр & 5.0 & 4.4 & $-0.6 / 12$ \\
\hline 10 & б/н в 0.8 км к В от н.п. Барановка & № 9, лв & 0.8 & прсх & $-0.8 / 100$ \\
\hline 11 & б/н в 0.8 км к В от н.п. Барановка & », лВ & 2.5 & 1.8 & $-0.7 / 28$ \\
\hline 12 & б/н в 0.8 км к В от н.п. Бейнарка & », лв & 1.5 & прсх & $-1.5 / 100$ \\
\hline 13 & б/н в 0.8 км к В от н.П. Борки & Каменка, лв & 4.2 & 2.5 & $-1.7 / 40$ \\
\hline 14 & б/н у н.п. Успеновка & », пр & 8.6 & 4.4 & $-4.2 / 49$ \\
\hline 15 & б/н в 0.8 км к В от н.п. Барановка & № 14, лв & 1.7 & 0.9 & $-0.8 / 47$ \\
\hline 16 & б/н в 0.7 км к ЮВ от н.п. Успеновка & Каменка, пр. & 3.4 & 2.1 & $-1.3 / 38$ \\
\hline 17 & б/н в 1.2 км к ЮЗ от н.п. Успеновка & № 16 , пр & 0.9 & 0.5 & $-0.4 / 44$ \\
\hline 18 & б/н в 1.8 км к Ю от н.П. Борки & Каменка, пр & 2.2 & 1.5 & $-0.7 / 32$ \\
\hline 19 & б/н у н.п. Яблоново & », пр & 4.1 & 2.3 & $-1.8 / 44$ \\
\hline \multirow[t]{2}{*}{20} & б/н на 3 н.П. Яблоново & № 19, пр & 1.8 & 0.8 & $-1.0 / 56$ \\
\hline & Суммарная протяженность, км & & 80.3 & 44.4 & $-35.9 / 45$ \\
\hline
\end{tabular}

Примечание. б/н -водоток без названия; н.п. - населенный пункт; С, В, 3, Ю и др. - стороны света; прсх - пересыхающий водоток.

бережный приток Дона на территории Липецкой области. Она впадает в главную реку на расстоянии 1553 км от устья, имеет протяженность от истока до устья 32.0 [22] и 33.4 км [11], а площадь водосбора $224 \mathrm{kм}^{2}$. В [22] указано, что р. Каменка имеет 3 притока длиной менее 10 км, общей протяженностью 9 км. Детальное изучение [11] выявило, что речную систему Каменки образуют очень малые водотоки в количестве 20 единиц длиной от 0.5 до 8.6 км.

Повторное обследование р. Каменка в летнюю межень 2018 г. [19] указывает на интенсивную деградацию речных водотоков, выразившуюся в полном или частичном пересыхании (табл. 2).

Из общего числа водотоков речной системы Каменки полностью в суходолы превратились 7 водотоков длиной от 0.5 до 1.5 км, суммарной протяженностью 6.0 км. На $60 \%$ сократилась в длине и системообразующая р. Каменка. С учетом изменений морфометрии речной системы с 2010 по 2018 г. скорость деградации составила около 4 км/год. Ее можно считать опасно высокой.

\section{ВЫВОД}

Антропогенное воздействие на водосборы в бассейне Верхнего Дона в настоящее время стабилизировалось, крупных изменений в землепользовании и водопользовании не наблюдается. Ведущими факторами современных деградационных изменений водотоков являются природные факторы, определяющие изменение водности, а именно - внутригодовое перераспределение сезонного стока, сокращение объемов весеннего половодья, особенности генезиса максимумов стока весеннего половодья, образования и продолжительности склонового стока, разрушение весенней ручейковой сети, происходящее на фоне современных климатических изменений.

\section{СПИСОК ЛИТЕРАТУРЫ}

1. Агафонов B.A. К истории формирования растительного покрова бассейна Среднего Дона // Вестн. Воронеж. ун-та. Сер. Химия. Биология. Фармация. Воронеж. 2005. № 2. С. 104-109.

2. Болгов М.В., Мишон В.М., Сенцова Н.И. Современные проблемы оценки водных ресурсов и водообеспечения. М.: Наука, 2005. 318 с. 
3. Водные ресурсы России и их использование / под ред. И.А. Шикломанова. СПб.: Гос. гидрологический ин-т, 2008. 600 с.

4. Вопросы географии / Русское географическое общество. Сб. № 145. Гидрологические изменения / В.М. Котляков, Н.И. Коронкевич, Е.А. Барабанова. М.: Кодекс, 2018. 432 с.

5. Давыдов Л.К. Гидрография СССР (воды суши). Ч. ІІ. Гидрография районов. Изд-во Ленинград. ун-та, $1955.600 \mathrm{c}$.

6. Девятова Т.А., Яблонских Л.А., Чувычкин А.Л., Титова Н.В. Экологический мониторинг малых рек бассейна Среднего Дона (на примере реки Девицы) / Современные экологические проблемы Центрально-Черноземного региона: Материалы заочной междунар. науч.-практ. конф. (г. Воронеж, 15 июля 2016 г.). Вып. 2: Особо охраняемые природные территории. Интродукция растений. Воронеж, 2016. С. 169-175.

7. Джамалов Р.Г., Киреева М.Б., Косолапов А.Е., Фролова Н.Л. Водные ресурсы бассейна Дона и их экологическое состояние. М.: ГЕОС, 2017. 205 с.

8. Дмитриева В.А. Гидрологическая изученность Воронежской области. Каталог водотоков / Воронеж: ИПЦ Воронеж. ун-та, 2008. 225 с.

9. Дмитриева В.А. Водные ресурсы Воронежской области в условиях меняющихся климата и хозяйственной деятельности / Воронеж: Изд. дом ВГУ, 2015. 192 c.

10. Дмитриева В.А., Бучик С.В. Генезис максимумов водности рек и изменчивость водного режима в современный климатический период // Водное хозяйство России: проблемы, технологии, управление. 2016. № 5. С. 50-62.

11. Дмитриева В.А., Илатовская Е.С. Гидрография рек Липецкой области. Каталог водотоков: монография. Липецк: БИ, 2010. 149 с.

12. Дмитриева В.А., Маскайкина С.В. Изменчивость водного режима в верховье Донского бассейна в современный климатический период // Вестн. Воронеж. ун-та. Сер. География. Геоэкология. 2013. № 1. C. 17-21.

13. Дмитриева В.А., Поваляев Н.Р. Временная трансформация морфометрии реки Сосна (Быстрая Сосна) - притока реки Дон // Современное ландшафтно-экологическое состояние и проблемы оптимизации природной среды регионов: Материалы XIII Междунар. ландшафт. конф., посвященной 100-летию со дня рождения Ф.Н. Милькова. (Воронеж, 14-17 мая 2018 г.) в 2 т. / ред. В.Б. Михно и др. Т. 1. Воронеж: ИСТОКИ, 2018. С. 187-190.

14. Зубащенко М.А. Основные черты морфологии коренного берега Среднего Дона // Науч. записки Воронеж. отд. географ. о-ва СССР. 1970. Вып. 2. С. 47-52.

15. Киреева М.Б., Фролова Н.Л. Современные особенности весеннего половодья рек бассейна Дона // Водное хозяйство России: проблемы, технологии, управление. 2013. № 1. С. 60-76.

16. Курдов А.Г. Батюшка Дон // Воронежские дали / под ред. Ф.Н. Милькова. Изд. 2, доп. Воронеж: Изд-во Воронеж. ун-та, 1981. С. 124-128.
17. Курдов А.Г. Реки Воронежской области (водный режим и охрана) / Воронеж: Изд-во Воронеж. унта, 1984. $164 \mathrm{c}$.

18. Мильков Ф.Н. Общие сведения о реке Дон и ее бассейне / Долина Дона: природа и ландшафты. Воронеж: Центрально-Черноземное кн. изд-во, 1982. C. 3-4.

19. Поваляев Н.Р. Современная морфометрия реки Каменка - притока реки Дон / Геоинформационное картографирование в регионах России: Материалы X Всерос. науч.-практ. конф. (Воронеж, ноябрь, 2018). Воронеж: Научная книга, 2018. С. 125-128.

20. По родным просторам / Ф.Н. Мильков, В.Н. Двуреченский, В.И. Федотов и др. Воронеж: Изд-во Воронеж. ун-та, 1992. 208 с.

21. Прожорина Т.И., Мажайская Е.А. Современное состояние водных ресурсов бассейна Среднего Дона // Вестн. Воронеж. ун-та. Сер. География. Геоэкология. Воронеж. 2005. № 1. С. 76-80.

22. Ресурсы поверхностных вод СССР. Гидрологическая изученность. Т. 7. Л.: Гидрометеоиздат, 1964. Донской район. 267 с.

23. Сапелкин Н.С., Смирнов С.В., Федотов В.И. Большой Дон: природа, культура, история, российскоукраинское пограничье. Воронеж, 2015. 400 с.

24. Семенов П.П. Географическо-статистический словарь Российской империи (в 5-и томах). Т. II. СПб., 1865. С. 119-124.

25. Смирнова А.Я., Бочаров В.Л. Водные экосистемы промышленно-городских агломераций бассейна Верхнего Дона // Вестн. Воронеж. ун-та. Сер. Геология. 1997. № 3. С. 102-115.

26. Современные и сценарные изменения речного стока в бассейнах крупнейших рек России. Ч. 2. Бассейны рек Волги и Дона: монография / Георгиади А.Г., Коронкевич Н.И., Милюкова И.П., Кашутина Е.А., Барабанова Е.А. Институт географии РАН. М.: МАКС-ПРЕСС, 2014. 216 c.

27. Схема комплексного использования и охраны водных объектов бассейна реки Дон.

http://www.donbvu.ru/activities/use_and_protection_don/ (дата обращения 30.08.2017).

28. Физико-географическое районирование центральных черноземных областей / под ред. Ф.Н. Милькова. Воронеж: Изд-во Воронеж. ун-та, 1961. 263 c.

29. Фролова Н.Л., Киреева М.Б., Агафонова С.А., Евстигнеев В.М., Ефремова Н.А., Повалишникова Е.С. Внутригодовое распределение стока равнинных рек европейской территории России и его изменение // Водное хозяйство России: проблемы, технологии, управление. 2015. № 4. С. 4-20.

30. Шмыков В.И., Смольянинов В.М., Жигулина Е.В. О вертикальной структуре ландшафтов в малых речных бассейнах Верхнего Дона // Современные ландшафтные исследования в контексте оптимизации рационального природопользования. Курск, 2015. C. 287-290. 


\title{
Modern Changes in the Water Regime and the Morphometry of Rivers in the Upper Don Basin
}

\author{
V. A. Dmitrieva\# \\ Voronezh State University, Voronezh, Russia \\ ${ }^{\#}$ e-mail: verba47@list.ru \\ Received January 1, 2019; revised February 22, 2019; accepted October 3, 2019
}

\begin{abstract}
The article substantiates the methodology of distinction between the Upper and the Middle basins of the Don river. The suggested demarcation line, undefined until now, should coincide with the administrative border of the Voronezh oblast in the south, south-east, east and north-east. This approach allows us to analyze the water regimen of the Don river proper and it's tributary, Khoper river, as an integrated Upper Don river basin. The annual river flow of the rivers Don and Khoper is diminishing, but the trend is weak and statistically insignificant. The duration of the spring snow floods is increasing due to its earlier onset and later ending. The peak water volumes have been steadily declining because of a change in the maximum water flow genesis under conditions of a steady increase of air temperature and decrease in frost penetration in the soil. The maximum flood levels are observed to occur more often in March, that was not registered before early 70 's, with the increase of floods repetition in May, whereas the April prevalence is diminishing. The absolute spring-fall low water minimums are shifting mostly towards September, while the winter ones tend to happen in February and March, right before the spring flood season. This leads to decreases in seasonal unevenness of the river runoff volume and increases the length of a relative "average water" periods throughout the year. The resulting negative dynamics in the river morphometry is due to the pre-spring thaws and floods, changes in the spring floods' genesis and character, lesser depth of the frost penetration, less contact between the soil and the flood waters, as well as destruction of the creek network and the slope runoff. We have registered the accelerated decrease in small watercourses, as well as the increase in the number of waterless valleys, dry waterbeds, and sporadic watercourses. The rivers Sosna and Kamenka, right-bank tributaries of the Don river, have demonstrated the 8.2 and $45 \%$ respective decrease in the riverbeds' length, the most prominent in the current century.
\end{abstract}

Keywords: Upper Don, hydrology regimen, river length, water flow dynamics, waterbed degradation

\section{REFERENCES}

1. Agafonov V.A. On the history of formation of vegetation cover of the Middle Don basin. Vestn. Voronezh. Gos. Univ., Ser.: Chimiya. Biol. Farmatsiya, 2005, no. 2, pp. 104-109. (In Russ.).

2. Bolgov M.V., Mishon V.M., Sentsova N.I. Sovremennye problemy otsenki vodnykh resursov $i$ vodoobespecheniya [Contemporary Challenges of Water Resources and Water Supply Assessment]. Moscow: Nauka Publ., 2005. $318 \mathrm{p}$.

3. Vodnye resursy Rossii i ikh ispol'zovanie [Water Resources of Russia and Their Usage]. Shiklomanova I.A., Ed. St. Petersburg: Gos. Gidrol. Inst., 2008. 600 p.

4. Voprosy geografii. Sb. 145: Gidrologicheskie izmeneniya [Problems of Geography. Vol. 145: Hydrological Changes]. Kotlyakov V.M., Koronkevich N.I., Barabanova E.A., Eds. Moscow: Kodeks Publ., 2018. 432 p.

5. Davydov L.K. Gidrografiya SSSR (vody sushi) [Hydrography of the USSR (Land Waters)]. Part II: Gidrografiya raionov [Hydrography of Regions]. St. Petersburg: Leningrad. Gos. Univ., 1955. 600 p.

6. Devyatova T.A., Yablonskikh L.A., Chuvychkin A.L., Titova N.V. Monitoring of small rivers of the Middle Don basin (on the example of the Devitsa river). In Sovremennye ekologicheskie problemy Tsentral'no-Chernozemnogo regiona [Modern Ecological Problems of the Central Black Soil Region]. Vol. 2: Osobookhranyaemye prirodnye territorii. Introduktsiya rastenii [Protected Ar- eas. Plant Introduction]. Voronezh, 2016, pp. 169-175. (In Russ.).

7. Dzhamalov R.G., Kireeva M.B., Kosolapov A.E., Frolova N.L. Vodnye resursy basseina Dona i ikh ekologicheskoe sostoyanie [Water Recourses of the Don River Basin and Their Ecological State]. Moscow: GEOS Publ., 2017. 205 p.

8. Dmitrieva V.A. Gidrologicheskaya izuchennost' Voronezhskoi oblasti. Katalog vodotokov [The State of Hydrological Exploration of Voronezh Region. Catalogue of Water Courses]. Voronezh: Voronezh. Gos. Univ., 2008. $225 \mathrm{p}$.

9. Dmitrieva V.A. Vodnye resursy Voronezhskoi oblasti v usloviyakh menyayushchikhsya klimata i khozyaistvennoi deyatel'nosti [Water Resources of Voronezh Region at the Background of Changing Climate and Economic Activities]. Voronezh: Voronezh. Gos. Univ., 2015. 192 p.

10. Dmitrieva V.A., Buchik S.V. Genesis of the rivers maximum water content and water regime variability in contemporary climatic period. Vodnoe Khozyaistvo Rossii: Problemy, Tekhnologii, Upravlenie, 2016, no. 5, pp. 50-62. (In Russ.).

11. Dmitrieva V.A., Ilatovskaya E.S. Gidrografiya rek $L i-$ petskoi oblasti. Katalog vodotokov [Hydrography of the Rivers of Lipetsk Region. Catalogue of Water Courses]. Lipetsk: BI Publ., 2010. 149 p.

12. Dmitrieva V.A., Maskaykina S.V. The variability of the water regime in the Upper Don basin in modern cli- 
matic period. Vestn. Voronezh. Gos. Univ., Ser.: Geogr. Geoekologiya, 2013, no. 1, pp. 17-21. (In Russ.).

13. Dmitrieva V.A., Povalyaev N.R. Timeline of the river Sosna (Bystraya Sosna) - tributary of the Don river morphometry transformation. In Sovremennoe landshaftno-ekologicheskoe sostoyanie i problemy optimizatsii prirodnoi sredy regionov. Mater. XIII Mezhd. landshaft. konf., posvyashch. 100-letiyu so dnya rozhdeniya F.N. Mil'kova (Voronezh, 14-17 maya 2018) [Current Landscape and Ecological State and Problems of Optimization of Natural Environment of Regions. Materials of XIII Int. Landscape Conf. Dedicated to 100-year Anniversary of F.N. Mil'kov (Voronezh, 14-17 May 2018)]. Mikhno V.B., Ed. Voronezh: ISTOKI Publ., 2018, vol. 1, pp. 187-190. (In Russ.).

14. Zubashchenko M.A. Main features of morphology of the valley side of the Middle Don. Nauchn. Zap. Voronezh. Otdela Geogr. O-va SSSR, 1970, no. 2, pp. 4752. (In Russ.).

15. Kireeva M.B., Frolova N.L. Current specifics of spring floods of the rivers of the basin of Don. Vodnoe Khozyaistvo Rossii: Problemy, Tekhnologii, Upravlenie, 2013, no. 1, pp. 60-76. (In Russ.).

16. Kurdov A.G. Father Don. In Voronezhskie dali [Voronezh Horizons], Mil'kova F.N., Ed. Voronezh: Voronezh. Gos. Univ., 1981, pp. 124-128. (In Russ.).

17. Kurdov A.G. Reki Voronezhskoi oblasti (vodnyi rezhim $i$ okhrana) [The Rivers of Voronezh Region (Water Regime and Protection)]. Voronezh: Voronezh. Gos. Univ., 1984. 164 p.

18. Mil'kov F.N. General information on the Don River and its basin. In Dolina Dona: priroda i landshafty [The Don Valley: Nature and Landscapes]. Voronezh: Central'no-Chernozemnoe Kn. Izd-vo Publ., 1982, pp. 3-4. (In Russ.).

19. Povalyaev N.R. Current morphometry of the Kamenka River - a tributary of the Don River. In Geoinformatsionnoe kartografirovanie $v$ regionakh Rossii: Mater. $X$ Vseros. nauch.-prakt. konf. (Voronezh, noyabr', 2018) [Geoinformation Mapping in Russian Regions: Materials of the X All-Russia Sci. Pract. Conf. (Voronezh, November 2018)]. Voronezh: Nauchn. Kniga Publ., 2018, pp. 125-128. (In Russ.).

20. Po rodnym prostoram [Across the Native Land]. Mil'kov F.N., Dvurechenskii V.N., Fedotov V.I., et al, Eds. Voronezh: Voronezh. Gos. Univ., 1992. 208 p.

21. Prozhorina T.I., Mazhaiskaya E.A. Current state of water resources of the Middle Don basin. Vestn. Voronezh.
Gos. Univ., Ser.: Geogr. Geoekol., 2005, no. 1, pp. 76-80. (In Russ.).

22. Resursy poverkhnostnykh vod SSSR. Gidrologicheskaya izuchennost' [Resources of the USSR Surface Waters. Degree of Hydrological Exploration. Leningrad: Gidrometeoizdat Publ., 1964, vol. 7, 267 p.

23. Sapelkin N.S., Smirnov S.V., Fedotov V.I. Bol'shoi Don: priroda, kul'tura, istoriya, rossiisko-ukrainskoe pogranich'e [The Great Don: Nature, Culture, History, Russian and Ukrainian Border Zone]. Voronezh, 2015. $400 \mathrm{p}$.

24. Semenov P.P. Geografichesko-statisticheskii slovar' Rossiiskoi imperii [Geographical and Statistical Dictionary of the Russian Empire]. St. Petersburg, 1865, vol. 2, pp. 119-124.

25. Smirnova A.Ya., Bocharov V.L. Water ecosystems of industrial and urban agglomerations of the Upper Don basin. Vestn. Voronezh. Gos. Univ., Ser.: Geologiya, 1997, no. 3, pp. 102-115. (In Russ.).

26. Sovremennye $i$ stsenarnye izmeneniya rechnogo stoka $v$ basseinakh krupneishikh rek Rossii [Current and Scenario Changes in River Flow in the Basins of the Largest Rivers of Russia]. Part 2: Basseiny rek Volgi i Dona [The Basins of the Volga and Don Rivers]. Georgiadi A.G., Koronkevich N.I., Milyukova I.P., Kashutina E.A., Barabanova E.A., Eds. Moscow: MAKSPRESS Publ., 2014. 216 p.

27. Scheme for the Integrated Use and Protection of Water Bodies of the Don River Basin. Available at: http://www.donbvu.ru/activities/use_and_protection_don/ (accessed: 30.08.2017). (In Russ.).

28. Fiziko-geograficheskoe raionirovanie tsentral'nykh chernozemnykh oblastei [Physical and Geographical Zoning of Central Black Soil Regions]. Mil'kov F.N., Ed. Voronezh: Voronezh. Gos. Univ., 1961. 263 p.

29. Frolova N.L., Kireeva M.B. Agafonova S.A., Evstigneev V.M., Efremova N.A., Povalishnikova E.S. Lowland rivers runoff within-year distribution and its changes on the European territory of Russia. Vodnoe Khozyaistvo Rossii: Problemy, Tekhnologii, Upravlenie, 2015, no. 4, pp. 4-20. (In Russ.).

30. Shmykov V.I., Smol'yaninov V.M., Zhigulina E.V. On the vertical structure of landscapes in small river basins of the Upper Don. In Sovremennye landshaftnye issledovaniya $v$ kontekste optimizatsii ratsional'nogo prirodopol'zovaniya [Current Landscape Science in the Context of Environmental Management Optimization]. Kursk, 2015, pp. 287-290. (In Russ.). 